\title{
МЕТАБОЛИТЫ АВТОТРОФНЫХ И ГЕТЕРОТРОФНЫХ ЛИСТЬЕВ AMAPAHTA Amaranthus tricolor L. COPTA EARLY SPLENDOR
}

\author{
М.С. ГИНС 1,3 , В.К. ГИНС1, С.М. МОТЫЛЕВА 2 , И.М. КУЛИКОВ 2 , \\ С.М. МЕДВЕДЕВ 2 , В.Ф. ПИВОВАРОВ1
}

\begin{abstract}
Важное направление системной биологии (метаболомики) - изучение состава и свойств низкомолекулярных метаболитов сельскохозяйственных растений с разным способом питания. Использование метаболомных технологий расширяет возможности анализа биохимических изменений в составе и структурных модификациях метаболитов, происходящих при переходе с автотрофного способа питания на гетеротрофный. Большинство фотосинтезирующих растений способно питаться автотрофно, однако в их жизни есть периоды появления бесхлорофилльных органов, которые питаются за счет органических веществ, запасенных ранее. Так, среди растений вида Amaranthus tricolor L. встречаются сорта, листья которых различаются по способу питания.
\end{abstract} Например, на растениях сорта Early Splendor в конце вегетативной фазы наряду с зеленоокрашенными фотосинтезирующими листовыми пластинками образуются ярко окрашенные красные гетеротрофные листья. Сравнительное изучение состава низкомолекулярных метаболитов в этих листьях актуально для понимания взаимосвязи гетерогенного и автотрофного способов питания в целом растении. В настоящей работе при метаболомном анализе водных и спиртовых экстрактов листьев амаранта сорта Early Splendor с использованием метода газовой хромато-массспектрометрии впервые установлены существенные качественные различия состава метаболитов в автотрофных и гетеротрофных листьях. В составе низкомолекулярных метаболитов идентифицированы как неспецифические (общие для разных способов питания), так и специфические (характерные для каждого из них в отдельности). Цель работы - сравнительное изучение состава низкомолекулярных метаболитов и выявление новых биологически активных метаболитовантиоксидантов в гетеротрофных и автотрофных листьях амаранта сорта Early Splendor. Эксперименты проводили в 2017-2019 годах. Объектом исследования были растения амаранта сорта Early Splendor в фазу конец цветения-начало формирования семян. Растения выращивали в пленочной теплице Федерального научного центра овощеводства. Материалом служили свежие красноокрашенные гетеротрофные листья, сформированные на верхушке главного побега, и нижележащие фотосинтезирующие листья растения. Исследовали листья с полностью сформированной листовой пластинкой. Листья измельчали и проводили экстракцию $96 \%$ этанолом или дистиллированной водой при соотношении 1:10 (навеска листьев:экстрагент) и температуре $24{ }^{\circ} \mathrm{C}$ в течение 30 мин. Анализ метаболитов выполняли методом газовой хромато-масс-спектрометрии на хроматографе JMS-Q1050GC («JEOL Ltd», Япония). По библиотечным масс-спектрам базы NIST-5 National Institute of Standards and Technology (США) идентифицировали 87 метаболитов, из которых в гетеротрофных листьях содержалось 19 веществ в водных экстрактах и 38 - в спиртовых, тогда как в фотосинтезирующих листьях было определено соответственно 21 и 57 веществ. В водных и спиртовых экстрактах обнаружили 29 одинаковых метаболитов. В гетеротрофных и автотрофных листьях амаранта вида сорта Early Splendor впервые был выявлен сквален (Сз0Н50) - биологически активное соединение, которое проявляет антиоксидантные свойства. Также в гетеротрофных листьях идентифицировано соединение монопеларгонин (monononanoin) (C15H1107), который служит промежуточным продуктом о-гликозилирования флавоноидов, относится к фенольным соединениям и обладает высокой антиоксидантной активностью. Были идентифицированы одинаковые метаболиты, характерные для листьев амаранта с разным типом питания, что позволяет сделать предположение о тесном взаимодействии двух способов питания в период появления, роста и развития гетеротрофных листьев. При этом фотосинтезирующие листья служили донорами ключевых метаболитов для гетеротрофных листьев, тогда как последние были не только акцепторами, но и сами могли синтезировать и модифицировать метаболиты, необходимые для построения клетки. Богатый состав углеводов, незаменимых аминокислот, липидов и органических кислот, идентифицированных в фотосинтезирующих листьях, обусловливает использование воспроизводимой листовой биомассы в качестве источника антиоксидантов и биологически активных веществ. Следует подчеркнуть, что не все метаболиты удалось идентифицировать. Тем не менее выявленный нами набор метаболитов, поступающих из фотосинтезирующих листьев, позволяет предположить, что этих веществ достаточно для построения и функционирования клеток и тканей гетеротрофных листьев.

Ключевые слова: Amaranthus tricolor, низкомолекулярные антиоксиданты, автотрофный лист, гетеротрофный лист, газовая хроматография, масс-спектрометрия.

Большинство фотосинтезирующих растений способны питаться ав- 
тотрофно, однако в их жизни есть периоды появления бесхлорофилльных органов (цветки, листья, луковицы и др.), которые питаются за счет органических веществ, запасенных ранее. Важность изучения гетеротрофного питания определяется тем, что все не зеленные органы и клетки растения в темноте питаются гетеротрофно.

Растения амаранта (Amarantus tricolor L.) широко распространены по всему миру и служат источником жизненно необходимых пищевых компонентов (1-3). Здоровое питание - важный элемент жизнедеятельности человека. Дефицит эссенциальных нутриентов биологически активных веществ и минеральных элементов представляет серьезную угрозу для здоровья (4). Чем больше информации о составе и свойствах пищевых и фармакологических метаболитов в листьях амаранта будет получено, тем эффективнее будут создаваться безопасные функциональные продукты. В листьях амаранта содержатся витамины и минералы (5-7), а также красные бетацианины и желтые бетаксантины, флавоноиды и другие физиологически активные соединения, которые проявляют антиоксидантные свойства (8-11).

Удобный объект для изучения состава органических веществ в фотосинтезирующих и бесхлорофилльных листьях - растения вида Amarantus tricolor L. сорта Early Splendor. Хотя растения этого сорта относятся к листовым овощным, они настолько декоративны, что их используют также для украшения клумб. В процессе развития они проходят несколько этапов, характерных только для Early Splendor: появление на вершине побега после завершения его роста ярко-красных гетеротрофных листьев, образование зеленого пятна на кончике каждого красного листа и постепенное распространение по всему листу зеленой зоны, экранирующей красную окраску.

Ранее сообщалось, что суммарное содержание антиоксидантов, фотосинтетических пигментов и бетацианинов в фотосинтезирующих и гетеротрофных листьях сорта Early Splendor различается. При этом гетеротрофная ткань красных листьев содержит следовые количества хлорофилла и не способна к фотосинтезу (12). Подавление накопления хлорофилла в красных листьях было показано в ряде работ $(13,14)$. При оценке экспрессии девяти генов, кодирующих восемь ферментов, которые участвуют в биосинтезе хлорофилла, наблюдали снижение экспрессии гена НАДФН-протохлорофиллидоксидоредуктазы. Она катализирует одну из стадий биосинтеза хлорофилла, и, как следствие, снижение экспрессии гена НАДФ-Н-протохлорофиллидоксидоредуктазы вызывает потерю способности синтеза этого важного фотосинтетического пигмента, что играет ключевую роль в формировании красных листьев $A$. tricolor и его способа питания. Гиперсинтез красноокрашенного пигмента амарантина также может регулироваться посредством изменения экспрессии генов $(15,16)$.

Известно, что автотрофные листья в процессе фотосинтеза используют неорганические субстраты, тогда как гетеротрофные листья этого же растения - готовые органические соединения, синтезированные в нем раннее (17). Однако вопрос о составе основных групп низкомолекулярных метаболитов, образованных в разнокачественных листьях, различающихся типом питания, недостаточно изучен.

В настоящей работе при метаболомном анализе водных и спиртовых экстрактов листьев амаранта сорта Early Splendor с использованием метода газовой хромато-масс-спектрометрии впервые установлены существенные качественные различия состава метаболитов в автотрофных и гетеротрофных листьях. В составе низкомолекулярных метаболитов идентифицированы как неспецифические (общие для разных способов питания), так и специфические (характерные для каждого из них в отдельно- 
сти) метаболиты. Расширены представления о формировании приспособительных изменений в клетке при переходе от фототрофного к гетеротрофному питанию посредством изменения состава и свойств низкомолекулярных метаболитов.

Цель работы - сравнительное изучение состава низкомолекулярных метаболитов и выявление новых биологически активных метаболитовантиоксидантов в гетеротрофных и автотрофных листьях амаранта сорта Early Splendor.

Методика. Работу проводили в 2017-2019 годах на растениях Amarantus tricolor L. сорта Early Splendor в фазу конец цветения-начало формирования семян. Растения выращивали в пленочной теплице Федерального научного центра овощеводства.

Материалом для анализа служили свежие красноокрашенные гетеротрофные листья, сформированные на верхушке главного побега, и нижележащие фотосинтезирующие листья растения. Исследовали листья с полностью сформированной листовой пластинкой. Листья измельчали на гомогенизаторе A11 basic («IКA», Германия) и проводили экстракцию $96 \%$ этанолом или дистиллированной водой при соотношении 1:10 (навеска листьев:экстрагент) и температуре $24{ }^{\circ} \mathrm{C}$ в течение 30 мин. Анализ метаболитов выполняли методом газовой хромато-масс-спектрометрии (ГХ-МС) на хроматографе JMS-Q1050GC («JEOL Ltd», Япония).

Использовали капиллярную колонку DB-5HT («Agilent», США; длина 30 м, внутренний диаметр 0,25 мм, толщина пленки 0,52 мкм, газноситель - гелий). Температурный градиент составлял от 40 до $280{ }^{\circ} \mathrm{C}$, температура инжектора и интерфейса - $250{ }^{\circ} \mathrm{C}$, ионного источника $200{ }^{\circ} \mathrm{C}$. Скорость потока газа в колонке 2,0 мл/мин, время анализа 45 мин, режим ввода с делением потока, объем вводимой пробы 1-2 мкл упаренного экстракта. Дериватизацию проводили с использованием силирующего агента N,O-бис(триметилсилил)трифторацетамида (БСТФА) согласно методике, описанной R.J. Robbins (18). Идентификацию веществ осуществляли по параметрам удерживания и масс-спектрам библиотеки NIST-5 National Institute of Standards and Technology (https://www.nist.gov, США). Диапазон сканирования 33-900 m/z. Достоверная вероятность определения идентифицированных веществ находилась в пределах 75-98 \%.

Результаты. Характерные ГХ-МС-профили водного и спиртового экстрактов гетеротрофных листьев амаранта сорта Early Splendor представлены на рисунке (А, Б). В результате анализа состава соединений идентифицировали 87 метаболитов, из которых в водных экстрактах обнаружили 33, в спиртовом - 74 (табл.).

Группа органических кислот была представлена 22 соединениями, включая кислоты алифатического ряда, циклические и высокомолекулярные, которые характеризовались наличием в молекуле одной или нескольких карбоксильных групп (см. табл.). В клетке органические кислоты находятся как в связанном, так и в свободном виде. Физиологическая роль органических кислот заключатся в их защитных антибактериальных и антиоксидантных свойствах, а также в способности образовывать буферные системы в клеточном соке, участвовать в цикле Кребса. В водном экстракте гетеротрофных листьев амаранта идентифицировали 5 органических кислот, тогда как в спиртовом - 9. При этом бромсебациновую, моноамидоэтилмалоновую и янтарную кислоты обнаружили в обоих экстрактах гетерогенных листьев. Фенольные кислоты (бензойная, фенилуксусная и фталевая) были идентифицированы только в автотрофных листьях.

Важным метаболитом, выявленным в спиртовом экстракте, была 
пантотеновая кислота (витамин В5) - амид аминокислоты $\beta$-аланина и пантотеновой кислоты. Пантотеновая кислота в качестве кофермента в составе КоА осуществляет более 130 метаболических реакций, участвуя в синтезе жирных кислот, стеролов, глицеридов, лимонной кислоты и других соединений (19).

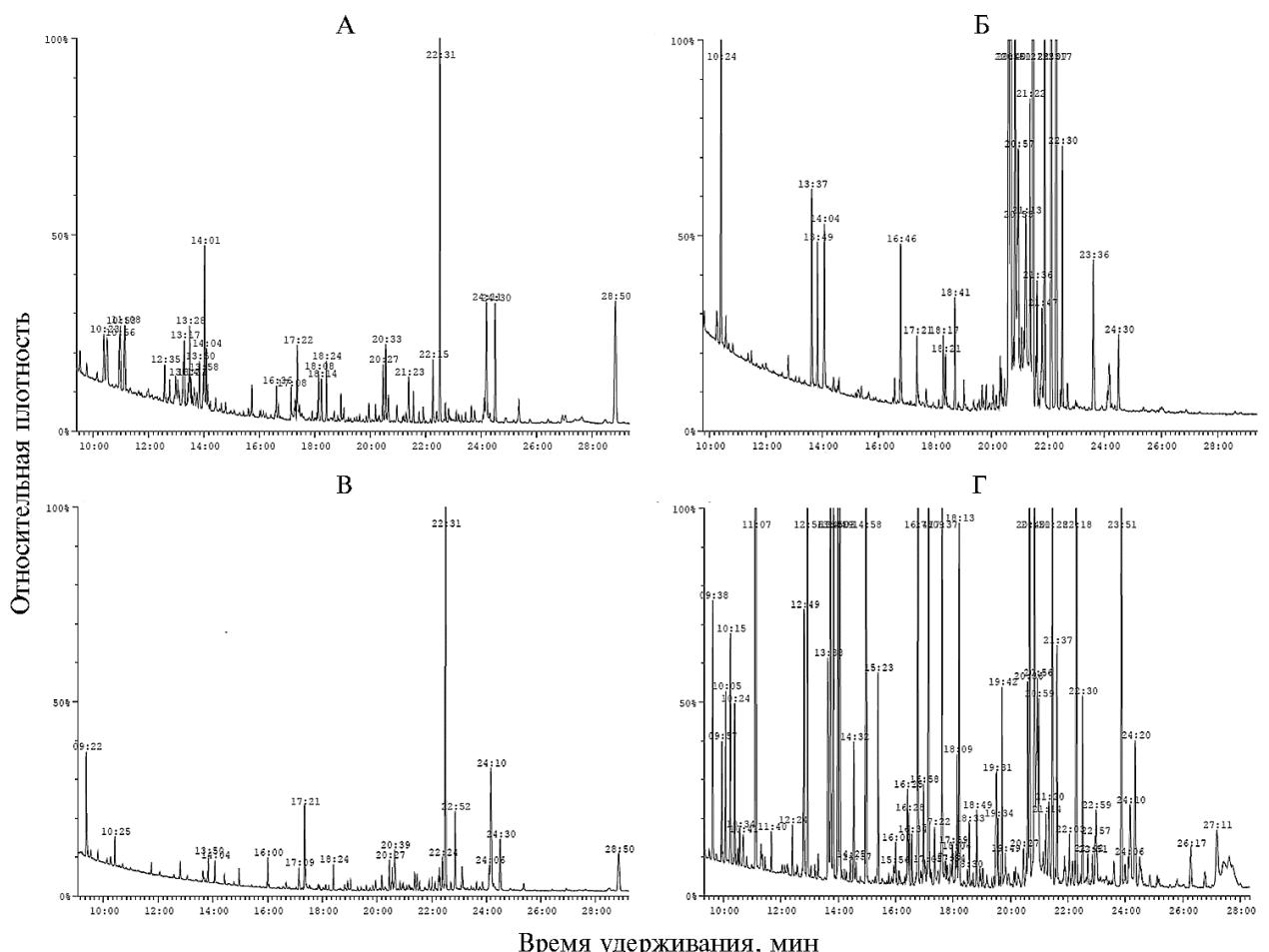

Хроматографические профили водного (слева) и этанольного (справа) экстрактов из гетеротрофных (А, Б) и фотосинтезирующих (В, Г) листьев амаранта Amaranthus tricolor L. copта Early Splendor. Газовый хромато-масс-спектрометр JMC-Q1050GC («JEOL Ltd», Япония)

Метаболиты, выявленные в экстрактах гетеротрофных и фотосинтезирующих тканей листьев амаранта (Amarantus tricolor L.) сорта Early Splendor методом хромато-масс-спектрометрии

\begin{tabular}{|c|c|c|}
\hline $\mathrm{Rt}$, мин & Соединение & Экстракт \\
\hline $20 \cdot 02$ & 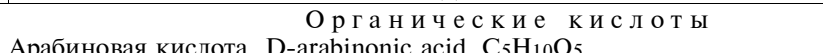 & ЭГ ЭФ \\
\hline $19: 57$ & Азелаиновая кислота, Azelainic acid, $\mathrm{C}_{9} \mathrm{H}_{16} \mathrm{O} 4$ & ВГ, ВФ \\
\hline $22: 42$ & 2-Бромосебациновая кислота, 2-Bromosebacic acid, $\mathrm{C}_{10} \mathrm{H}_{17} \mathrm{O} 4 \mathrm{Br}$ & ВГ, ЭГ \\
\hline $10: 23$ & Бутановая кислота, Butanoic acid, $\mathrm{C}_{4} \mathrm{H}_{8} \mathrm{O}_{2}$ & $Э Ф$ \\
\hline $27 ; 25$ & Додекандионовая, Dodecanedioic acid, $\mathrm{C}_{12} \mathrm{H}_{22} \mathrm{O}_{2}$ & $Э Ф$ \\
\hline 17:59 & Глутаровая кислота, Glutaric acid, $\mathrm{C}_{5} \mathrm{H}_{8} \mathrm{O}_{4}$ & ВГ, ЭФ \\
\hline $22: 23$ & 2 -Гидроксимасляная кислота, 2-Hydroxyoctanoic acid, $\mathrm{C}_{4} \mathrm{H}_{8} \mathrm{O}_{3}$ & $\mathrm{~B} \Phi$ \\
\hline 12:09 & Моноамидоэтилмалоновая, Monoamidoethylmalonic acid, $\mathrm{C}_{14} \mathrm{H}_{33} \mathrm{NO}_{3}$ & ВГ, ЭГ, ЭФ \\
\hline $16: 33$ & Малеиновая кислота, Malic acid, $\mathrm{C}_{4} \mathrm{H}_{6} \mathrm{O}_{5}$ & ЭГ, ЭФ \\
\hline $14: 59$ & Малоновая кислота, Malonic acid, $\mathrm{C}_{3} \mathrm{H}_{4} \mathrm{O}_{4}$ & ЭГ, ЭФ \\
\hline $10: 24$ & Молочная кислота, Lactic acid, $\mathrm{C}_{3} \mathrm{H}_{6} \mathrm{O}_{3}$ & ЭГ, ЭФ \\
\hline $20: 47$ & Валериановая кислота, Pentonic acid, $\mathrm{C}_{5} \mathrm{H}_{10} \mathrm{O}_{2}$ & ЭГ, ЭФ \\
\hline 20:11 & 10-Ундециловая кислота, 10-Undecynoic acid, $\mathrm{C}_{11} \mathrm{H}_{22} \mathrm{O}_{2}$ & ВФ \\
\hline $14: 58$ & Эритроновая кислота, Erythronic acid, $\mathrm{C}_{18} \mathrm{H}_{30} \mathrm{O}_{5}$ & $Э Ф$ \\
\hline 22:59 & Эритро-пентановая кислота, Erythro-pentonic acid, $\mathrm{C}_{6} \mathrm{H}_{12} \mathrm{O}_{2}$ & $Э Ф$ \\
\hline 13:09 & Яблочная кислота, DL-malic (Butanedioic) acid, $\mathrm{C}_{4} \mathrm{H}_{4} \mathrm{O}_{5}$ & ЭФ \\
\hline 14:04 & Янтарная кислота, Succinic acid, $\mathrm{C}_{4} \mathrm{H}_{4} \mathrm{O}_{4}$ & ВГ, ЭГ \\
\hline $17: 47$ & 2-Изопропил малеиновая кислота, 2-Isopropylmalic acid, $\mathrm{C}_{4} \mathrm{H}_{4} \mathrm{O}_{4}$ & $Э Г$ \\
\hline 22:04 & $\begin{array}{c}\text { Пантотеновая кислота (витамин В5), Pantothenic acid, } \mathrm{C}_{9} \mathrm{H}_{17} \mathrm{O}_{5} \\
\text { Ф е н о л ь н ы е к и с л о т ы }\end{array}$ & $Э Г$ \\
\hline $19: 37$ & Бензойная кислота, Benzoic acid, $\mathrm{C}_{7} \mathrm{H}_{6} \mathrm{O}_{2}$ & ВФ \\
\hline 21:09 & Фенилуксусная кислота, Phenylacetic acid, $\mathrm{C}_{8} \mathrm{H}_{8} \mathrm{O}_{2}$ & ЭФ \\
\hline 22:51 & Изоферуловая кислота, Isoferulic acid, $\mathrm{C}_{10} \mathrm{H}_{13} \mathrm{O}_{4}$ & ВФ \\
\hline $21: 23$ & Фталевая кислота, Phthalic acid, $\mathrm{C}_{8} \mathrm{H}_{12} \mathrm{O}_{4}$ & ВФ \\
\hline
\end{tabular}



Ве ществ углеводной при роды

L-Арабитол, L-(-)-Arabitol, $\mathrm{C}_{5} \mathrm{H}_{12} \mathrm{O}_{5}$

Арабинопираноза, $\beta$-DL-Arabinopyranose, $\mathrm{C}_{5} \mathrm{H}_{12} \mathrm{O}_{5}$

$Э Ф$

Галактопираноза, $\beta$-L-Galactopyranose, $\mathrm{C}_{6} \mathrm{H}_{13} \mathrm{O}_{8}$

Галактоза, D-Galactose, C6 $\mathrm{H}_{16} \mathrm{O}_{6}$

Ксилоза, $\beta$-D-Xylopyranose, $\mathrm{C}_{6} \mathrm{H}_{10} \mathrm{O}_{5}$

Маннит, D-Mannitol, $\mathrm{C}_{6} \mathrm{H}_{12} \mathrm{O}_{6}$

Рибитол, Ribitol, $\mathrm{C}_{5} \mathrm{H}_{12} \mathrm{O}_{5}$

Эритрофураноза, $\beta$-Erythrotetrofuranose, $\mathrm{C}_{5} \mathrm{H}_{14} \mathrm{O}_{5}$

Рибоновая кислота, Ribonic acid, pentakis, $\mathrm{C}_{5} \mathrm{H}_{12} \mathrm{O}_{5}$

Глюкопираноза, $\beta$-D-Glucopyranose, $\mathrm{C}_{6} \mathrm{H}_{6} \mathrm{O}_{6}$

Ликсоза, $\beta$-(DL)-Lyxopyranose, $\mathrm{C}_{5} \mathrm{H}_{10} \mathrm{O}_{5}$

Левокгюкозан, Levoglucosan, $\mathrm{C}_{6} \mathrm{H}_{10} \mathrm{O}_{5}$

Маннобиоза, 3- $\alpha$-Mannobiose, $\mathrm{C}_{12} \mathrm{H}_{22} \mathrm{O}_{11}$

Тагатоза, D-(-)-Tagatofuranose, $\mathrm{C}_{6} \mathrm{H}_{12} \mathrm{O}_{6}$

Сорбоза, L-(-)-Sorbose, $\mathrm{C}_{6} \mathrm{H}_{12} \mathrm{O}_{6}$

Сорбофураноза, $\alpha-1-(-)$ Sorbofuranose, $\mathrm{C}_{6} \mathrm{H}_{12} \mathrm{O}_{6}$

Рибоза, D-(-)-Ribofuranose, $\mathrm{C}_{5} \mathrm{H}_{10} \mathrm{O}_{5}$

Фруктоза, D-(-)-Fructofuranose, $\mathrm{C}_{5} \mathrm{H}_{8} \mathrm{O}_{6}$

Фруктопираноза, D-(-)-Fructopyranose, $\mathrm{C}_{5} \mathrm{H}_{8} \mathrm{O}_{6}$

Тураноза, D-(+)-Turanose, $\mathrm{C}_{6} \mathrm{H}_{12} \mathrm{O}_{6}$

Талоза, D-(+)-Talofuranose, $\mathrm{C}_{5} \mathrm{H}_{12} \mathrm{O}_{6}$

Рибит, Ribitol, $\mathrm{C}_{5} \mathrm{H}_{12} \mathrm{O}_{5}$

Глицерил гликозид, Glyceryl-glycoside

Глюкофуранозид, Glucofuranoside, $\mathrm{C}_{6} \mathrm{H}_{12} \mathrm{O}_{6}$

Глюконовой кислоты лактон, Gluconic acid, $\gamma$-lacton, $\mathrm{C}_{6} \mathrm{H}_{12} \mathrm{O}_{6}$

Инозит, Inositol, $\mathrm{C}_{6} \mathrm{H}_{12} \mathrm{O}_{6}$

Лактон рибоновой кислоты, D-(+)-Ribono-1,4-lactone, $\mathrm{C}_{5} \mathrm{H}_{12} \mathrm{O}_{5}$

Глюконовой кислоты лактон, Gluconic acid, $\gamma$-lacton, $\mathrm{C}_{6} \mathrm{H}_{10} \mathrm{O}_{6}$

Глицерин, Clycerol, $\mathrm{C}_{3} \mathrm{H}_{8} \mathrm{O}_{3}$

Кротонолактон, 2(3H)-Furanone, $\mathrm{C}_{4} \mathrm{H}_{4} \mathrm{O}_{2}$ Ам инокислоты и их производные

L-Аланин, L-Alanin, $\mathrm{C}_{3} \mathrm{H}_{7} \mathrm{NO}_{2}$

L-Лейцин, L-Leucine, $\mathrm{C}_{6} \mathrm{H}_{13} \mathrm{NO}_{2}$

L-Изолейцин, L-Isoleucine, $\mathrm{C}_{6} \mathrm{H}_{13} \mathrm{NO}_{2}$

L-Аспарагиновая кислота, L-Aspartic acid, $\mathrm{C}_{4} \mathrm{H}_{7} \mathrm{NO}_{4}$

$\mathrm{L}-$ Аспарагин, амид аспарагиновой кислоты, L-Asparagin, $\mathrm{C}_{4} \mathrm{H}_{8} \mathrm{~N}_{2} \mathrm{O}_{3}$

L-Пролин, L-Proline, $\mathrm{C}_{3} \mathrm{H}_{9} \mathrm{NO}_{2}$

$\mathrm{L}-$-Гомосерин, L-Homoserine, $\mathrm{C}_{4} \mathrm{H}_{9} \mathrm{NO}_{3}$

$\mathrm{L}-\mathrm{Cерин,} \mathrm{L-Serin,} \mathrm{C}_{3} \mathrm{H}_{7} \mathrm{~N}_{1} \mathrm{O}_{3}$

L-Валин, L-Valin, $\mathrm{C}_{5} \mathrm{H}_{11} \mathrm{NO}_{2}$

L-Tреонин, L-Treonin, $\mathrm{C}_{4} \mathrm{H}_{9} \mathrm{NO}_{3}$

L-Тирозин, L-Tyrosine, $\mathrm{C}_{9} \mathrm{H}_{17} \mathrm{NO}_{2}$

$\mathrm{L}$-Фенилаланин, L-Phenylalanin, $\mathrm{C}_{9} \mathrm{H}_{18} \mathrm{NO}_{2}$

L-Цистатион, L-Cistatione, $\mathrm{C}_{7} \mathrm{H}_{14} \mathrm{~N}_{2} \mathrm{O}_{2}$

Т ер пен ы

Сквален, Squalen, $\mathrm{C}_{30} \mathrm{H}_{50}$

Борнеол, Borneol, $\mathrm{C}_{10} \mathrm{H}_{18} \mathrm{O}$

Изоборнеол, Izoborneol, $\mathrm{C}_{10} \mathrm{H}_{18} \mathrm{O}$

Дегидроабиетиновая кислота, Dehydroabietic acid, $\mathrm{C}_{20} \mathrm{H}_{29} \mathrm{O}$

$$
\text { Други е соединения }
$$

Токоферол (витамин Е), (+)- $\alpha$-Tocopherol, $\mathrm{C}_{29} \mathrm{H}_{50} \mathrm{O}_{2}$

ВГ, ЭГ, ЭФ

$\mathrm{B} Г, \mathrm{~B} Ф, Э Ф$

ЭГ, ВФ, ЭФ

$Э Г$

ЭФ

ВФ, ЭФ

ЭФ

ЭФ

$\ni Ф$

ЭФ

ВФ, ЭФ

ЭФ

ЭГ, ЭФ

ЭФ

ЭГ, ВФ, ЭФ

ВГ, ЭГ, ЭФ

ЭФ

ВФ, ЭФ

ЭФ

ЭГ

ЭГ

$Э Ф$

$Э Ф$

$Э Ф$

$Э Ф$

ЭГ, ЭФ

ВГ, ЭГ

ВГ, ЭГ, ВФ, ЭФ

ЭГ

ЭГ, ВФ, ЭФ

ЭГ, ЭФ

ЭФ

ЭФ

ЭФ

ЭГ, ЭФ

ЭГ

ЭФ

ЭГ, ЭФ

ЭГ, ЭФ

ЭФ

ЭФ

ЭГ

ВГ, ЭГ, ВФ, ЭФ

$\mathrm{B \Gamma}$

$\mathrm{B} \Gamma$

$\mathrm{B} \Gamma$

ЭФ

ВФ, ЭФ

ЭГ

ЭГ

ЭГ, ВФ

ВГ, ВФ

ЭФ

ЭГ

ЭФ

$\begin{array}{lll}\text { 16:08 } & \text { Пироглутаминовая кислота, 2-Pyrrolidone-5-carboxylic acid, } \mathrm{C}_{9} \mathrm{H}_{27} \mathrm{~N}_{2} \mathrm{O}_{4} & \text { ЭГ } \\ \text { 16:28 } & \text { Пиримидинтрион, 2,4(1H,3H)-Pyromidinedione, } \mathrm{C}_{4} \mathrm{H}_{4} \mathrm{~N}_{2} \mathrm{O}_{3} & \text { ЭФ }\end{array}$

$\begin{array}{lll}\text { 16:08 } & \text { Пироглутаминовая кислота, 2-Pyrrolidone-5-carboxylic acid, } \mathrm{C}_{9} \mathrm{H}_{27} \mathrm{~N}_{2} \mathrm{O}_{4} & \text { ЭГ } \\ \text { 16:28 } & \text { Пиримидинтрион, 2,4(1H,3H)-Pyromidinedione, } \mathrm{C}_{4} \mathrm{H}_{4} \mathrm{~N}_{2} \mathrm{O}_{3} & \text { ЭФ }\end{array}$

При м еч ан и е. Rt - время удерживания, ВГ - водный экстракт из гетеротрофных тканей, ЭГ спиртовой экстракт из гетеротрофных тканей, ВФ - водный экстракт из фотосинтезирующих тканей, ЭФ спиртовой экстракт из фотосинтезирующих тканей. 
Следующая группа соединений, выявленная посредством метаболического профилирования, относится к жирным кислотам, которые содержат в своей молекуле кислотную группу - СООН (карбоксильную). Жирные кислоты служат компонентами липидов и выполняют защитные функции. В состав липидов помимо жирных кислот входит спирт глицерол, который был идентифицирован в водном и спиртовом экстрактах гетеротрофных листьев. В процессе адаптации растения к меняющимся условиям среды обитания важная роль отводится повышению содержания насыщенных и ненасыщенных жирных кислот и их соотношению, обусловливающим стабильность липидных компонентов мембран $(20,21)$.

В гетеротрофных и автотрофных листьях были идентифицированы две насыщенные жирные кислоты (пальмитиновая и стеариновая) и одна ненасыщенная (линолевая). Кроме того, в водном экстракте гетеротрофных листьев мы обнаружили две насыщенные жирные кислоты - миристиновую $\left(\mathrm{C}_{14} \mathrm{H}_{28} \mathrm{O}_{2}\right)$ и лауриновую $\left(\mathrm{C}_{10} \mathrm{H}_{20} \mathrm{O}_{2}\right)$, что свидетельствует о высокой адаптивности фотосинтезирующих листьев.

Низкомолекулярные сахара и многоатомные спирты выполняют в растении защитные функции, проявляя осмопротекторные и антиоксидантные свойства, а также могут входить в состав сигнальных систем (22). Моносахариды служат источниками энергии и питательных веществ, используются как строительные блоки для синтеза полисахаридов. Группа веществ углеводного происхождения наиболее многочисленная и представлена 30 соединениями - простыми углеводами, сахарными спиртами и лактонами. Анализ компонентов углеводного происхождения в гетеротрофных листьях амаранта выявил 12 веществ углеводной природы, в том числе 2 многоатомных спирта - глицерин и рибит. В водном экстракте содержалось только 4 углеводных метаболита - лактон глюконовой кислоты, арабинопираноза, галактопираноза и рибоза.

Аминокислоты - важные биологически активные соединения, обладающие физиологической активностью. В живом организме они служат структурными элементами синтезируемых белковых молекул и участвуют в разнообразных реакциях обмена веществ, формировании устойчивости растений к стрессам различной природы, процессах детоксикации ксенобиотиков (23). В спиртовом экстракте гетеротрофных листьев мы выявили 6 аминокислот, из них 3 незаменимые - валин, треонин, лейцин. Следует отметить, что цистатион служит промежуточным продуктом при биосинтезе метионина.

Метаболиты терпеновой природы (борнеол, изоборнеол, дегидроабиетиновая кислота, сквален) были идентифицированы в водном экстракте, тогда как в спиртовом определены фитостеролы, участвующие в синтезе холестерина (сквален и стигмастерол). Уникальный фитостерол сквален $\left(\mathrm{C}_{30} \mathrm{H} 50\right)$, обнаруженный в гетеротрофных листьях, проявляя антиканцерогенную активность и ранозаживляющее действие в организме человека и будучи мощным антиоксидантом, способствует интенсивному метаболизму в живой клетке (24). Как компонент пищи или как специальная пищевая добавка сквален снижает содержание холестерина. Ранее мы впервые идентифицировали сквален в водном экстракте из листьев амаранта Amaranthus tricolor L. сорта Валентина (25). Сквален - исходное соединение, из которого образуются стероиды. В настоящее время в растениях обнаружен ряд соединений стероидной природы, которые ранее считались типичными для животных организмов, например холестеринпрегненолон и прогестерол (26).

Впервые в гетеротрофных листьях амаранта идентифицировано со- 
единение монопеларгонин (monononanoin) $\left(\mathrm{C}_{15} \mathrm{H}_{11} \mathrm{O}_{7}\right)$, который служит промежуточным продуктом о-гликозилирования флавоноидов, относится к фенольным соединениям и обладает высокой антиоксидантной активностью $(27,28)$.

Характерные профили водного и спиртового экстрактов автотрофных листьев амаранта сорта Early Splendor представлены на рисунке (B, Г). Методом ГХ-МС в фотосинтезирующих зелено-фиолетовых листьях были детектированы 67 соединений, причем 59 метаболитов, выделенных из автотрофных тканей, присутствовали в спиртовом экстракте, в то время как в водном был идентифицирован 21 метаболит (см. табл.).

Следует отметить, что в автотрофных листьях присутствовало больше органических кислот, чем в гетеротрофных. В водном экстракте автотрофных листьев мы обнаружили 5 органических кислот. Известно, что в листьях амаранта вида $A$. tricolor синтезируются природные антимикробные вещества с антиоксидантной активностью: малат, оксалацетат, ферулловая, бензойная, галловая и другие органические и фенольные кислоты, которые способствуют сохранности пищевых продуктов (29-32). При этом особое внимание среди природных метаболитов амаранта привлекают вышеуказанные органические и фенольные кислоты, участвующие в метаболических процессах в клетке (33-35).

В спиртовом экстракте фотосинтезирующих листьев амаранта были обнаружены органические кислоты разной химической природы (полиоксикарбоновые и фенилкарбоновые). Например, биологически активное соединение фенилуксусная кислота $\left(\mathrm{C}_{8} \mathrm{H}_{8} \mathrm{O}_{2}\right)$ служит растительным гормоном (ауксином).

Из жирных кислот пальмитиновую, стеариновую и линоленовую мы обнаружили как в водном, так и спиртовом экстрактах. Помимо этого, в водном экстракте присутствовали лауриновая и миристиновая насыщенные жирные кислоты.

В водном экстракте фотосинтезирующих листьев амаранта были идентифицированы 5 моносахаридов и многоатомный спирт рибит, в спиртовом экстракте дополнительно обнаружили эритрофуранозу и рибоновую кислоту (см. табл.). В спиртовом экстракте автотрофных листьев содержалось самое большое число моносахаридов и их производных - 24, из них 5 относилось к многоатомным спиртам: маннит, рибит, глицерин, арабитол, инозит (циклогексан-1,2,3,4,5,6-гексол) - витаминоподобное вещество (витамин В8).

В составе водного и спиртового экстрактов автотрофных листьев амаранта мы обнаружили незаменимые аминокислоты валин, лейцин, изолейцин, треонин, фенилаланин, а также такие стресс-протекторные аминокислоты, как серин, пролин, аспарагиновая кислота, аспарагин, аланин, тирозин, тогда как в гетеротрофных листьях присутствовали 6 аминокислот.

Ранее мы показали, что в листьях овощного амаранта A. tricolor сорта Валентина содержится полный набор свободных и связанных с белком незаменимых аминокислот, а также большое количество биологически активных метаболитов с антиоксидантной активностью, определяющих фармакологическое свойство биологически активной пищевой добавки - фиточая «Амарантил» $(7,36)$.

В спиртовом экстракте из фотосинтезирующих листьев амаранта также был обнаружен тригонеллин - бетаин, который образуется при метилировании никотиновой кислоты и играет существенную роль в азотном обмене у растений. Никотиновая кислота служит исходным веществом для синтеза тригонеллина $(31,37)$. 
Витамины группы Е, идентифицированные в спиртовом экстракте фотосинтезирующих листьев, будучи сильными антиокислителями, регулируют интенсивность свободно-радикальных реакций в клетке, защищая ненасыщенные жирные кислоты липидов мембран от окисления. Токоферолы снижают риск возникновения хронических свободно-радикальных патологий и уменьшают активность фермента, отвечающего за синтез холестерина (38). На основе водных и спиртовых экстрактов биологически активных метаболитов листьев амаранта, идентифицированных в настоящей работе и полученных ранее (24), можно создавать безопасные функциональные продукты и лекарственные препараты, проявляющие антиоксидантное (39), гепатопротекторное $(40,41)$, антидиабетическое $(42,43)$ действие на организм человека.

Биохимический состав низкомолекулярных биологически активных веществ, в том числе обладающих антистрессовым и фармакологическим действием, активно изучается в различных органах амаранта, но особенно в листьях $(44,45)$. С появлением метаболомных технологий увеличился список идентифицированных низкомолекулярных метаболитов у амаранта разных видов (46). В листьях зелено- и красноокрашенных овощных и зерновых видов амаранта обнаружены соединения, представляющие ценность не только для пищевой, но и фармакологической промышленности: сквален, инозит, глицерин, стигмастерол, линолевая кислота, глюкопираноза, манноза и др., что аналогично данным, полученным в настоящей работе.

Особый интерес представляет проблема взаимосвязи гетеро- и фототрофных листьев. Метаболическое профилирование позволило установить, что в состав веществ углеводной природы гетеротрофных листьев амаранта сорта Early Splendor входило 13 из 29 веществ, присутствовавших в автотрофных листьях (см. табл.). Следует отметить, что в растении углеводы выполняют ключевую роль в качестве источников энергии и углеводных скелетов для органических соединений, запасных веществ, сигнальных молекул, а также участвуют в защитных реакциях растений при абиотических стрессах.

В состав моносахаридов в гетеротрофных листьях входили 8 соединений, что было существенно меньше по сравнению с автотрофными (13 соединений). Следует отметить, что среди последних не были идентифицированы ксилоза и талоза, которые участвуют в синтезе сложных углеводов. Выявленная способность моносахаридов экстрагироваться и водой, и спиртом из гетеротрофных (арабинопираноза и рибоза) и автотрофных (галактопираноза, галактоза, сорбофураноза и фруктофураноза) листьев указывает на амфифильные (осмопротекторные) свойства их молекул.

Метаболомное профилирование выявило 5 полициклических спиртов в фотосинтезирующих листьях, а в гетеротрофных были идентифицированы глицерин и рибит.

Моносахариды, полициклические спирты и пролин в листьях амаранта служат совместимыми осмолитами, которые способствуют поддержанию осмотического баланса клетки, стабилизации белков и клеточных структур, проявляя протекторную функцию. Однако в гетеротрофных листьях совместимых осмолитов содержалось существенно меньше по сравнению с автотрофными. Вероятно, в гетеротрофных листьях углеводы выполняют функцию сигнальных молекул и необходимы для построения мембранных структур клетки.

Представленные результаты позволяют предположить образование в гетеро- и автотрофных листьях амаранта трех пулов моносахаров и их производных, которые выполняют разные, возможно, взаимозаменяемые 
функции. Водорастворимый пул метаболитов углеводной природы играет определяющую роль в метаболизме клетки, обеспечивая оптимальную активность реакций обмена веществ в цитоплазме и антиоксидантную защиту. Спирторастворимый пул моносахаридов и их производных обеспечивает сохранение структур клетки и их активности. Пул амфифильных моносахаров и их производных поддерживает осмотический баланс, участвует в стабилизации белков и клеточных структур и антиоксидантной защите.

В растениях амаранта сорта Early Splendor после завершения роста главного побега и начала развития из его апекса клеток гетеротрофной ткани между красными и фотосинтезирующими листьями возникают сложные метаболические связи. Мы предполагаем, что они осуществляются за счет транспорта ассимилятов из фотосинтезирующих листьев (донор) к новообразованным растущим гетеротрофным листьям (акцептор). При этом 37 низкомолекулярных метаболитов из фотосинтезирующих листьев были обнаружены в гетеротрофных тканях красных листьев. Это вещества углеводной природы, а также органические кислоты, аминокислоты и основные жирные кислоты. Одинаковые метаболиты, обнаруженные в гетеротрофных и автотрофных листьях, видимо, служат ключевыми для формирования гетеротрофной ткани.

Таким образом, с использованием газовой хромато-масс-спектрометрии в водных и спиртовых экстрактах фотосинтезирующих и гетеротрофных листьев амаранта сорта Early Splendor мы идентифицировали 87 низкомолекулярных метаболитов, включая органические кислоты, моносахариды и их производные, жирные кислоты, аминокислоты и вторичные соединения (фенольные соединения, терпены, гликозиды). При этом гетеротрофные листья содержат почти в 1,5 раза меньше метаболитов по сравнению с фотосинтезирующими. Наличие как неспецифических, так и специфических метаболитов, с одной стороны, указывает на тесное взаимодействие двух способов питания, с другой - на способность синтезировать и модифицировать метаболиты, что свидетельствует о частичной автономности гетеротрофных листьев. Большинство из выявленных соединений имеют пищевую и фармакологическую ценность, поэтому листья амаранта сорта Early Splendor следует рассматривать как перспективное сырье для разработки биологически активных добавок к пище и фитопрепаратов диетического и профилактического назначения. Обнаружение одинаковых метаболитов указывает на перспективность дальнейшего изучения взаимодействия автотрофной и гетеротрофной тканей.

\section{ЛИТЕРАТУРА}

1. Hilou A., Ouedraogo I., Sombié P., Guenné S., Paré D., Compaoré M. Leafy amaranthus consumption patterns in Ouagadougou, Burkina Faso. African Journal of Food, Agriculture, Nutrition and Development, 2016, 16(4): 11248-11264 (doi: 10.18697/ajfand.76.13810).

2. Li H., Deng Z., Liu R., Zhu H., Draves J., Marcone M., Sun Y., Tsao R. Characterization of phenolics, betacyanins and antioxidant activities of the seed, leaf, sprout, flower and stalk extracts of three Amaranthus species. Journal of Food Composition and Analysis, 2015, 37: 75-81 (doi: 10.1016/j.jfca.2014.09.003).

3. Rastogi A., Shukla S. Amaranth: a new millennium crop of nutraceutical values. Critical Reviews in Food Science and Nutrition, 2013, 53(2): 109-125 (doi: 10.1080/10408398.2010.517876).

4. Гинс М.С., Гинс В.К., Кононков П.Ф. Антиоксидантный метаболом овощных культур. Вестник Российской сельскохозяйственной науки, 2016, 2: 55-58.

5. Kachiguma N., Mwase W., Maliro M., Damaliphetsa A. Chemical and mineral composition of amaranth (Amaranthus L.) species collected from central Malawi. Journal of Food Research, 2015, 4(4): 92-102 (doi: 10.5539/jfr.v4n4p92).

6. Sharma N., Gupta P. C., Rao C. V. Nutrient content, mineral content and antioxidant activity of Amaranthus viridis and Moringa oleifera leaves. Research Journal of Medicinal Plants, 2012, 
6(3): 253-259 (doi: 10.3923/rjmp.2012.253.259).

7. Gins M., Gins V., Momyleva, S., Kulikov I., Medvedev S., Kononkov P., Pivovarov V. Mineral composition of amaranth (Amaranthus L.) seeds of vegetable and grain usage by ARHIVBSP selection. Potravinarstvo Slovak Journal of Food Sciences, 2018, 12(1): 330-336 (doi: 10.5219/863).

8. Arunachalam V., Dhargalkar S., Vaingankar J., Kevat N. Pigment rich amaranth by tri-stimulus colorimetry and progeny test. National Academy Science Letters, 2016, 39(6): 411-415 (doi: 10.1007/s40009-016-0491-8).

9. Noori M., Talebi M., Nasiri Z. Seven Amaranthus L. (Amaranthaceae) taxa flavonoid compounds from Tehran Province, Iran. International Journal of Modern Botany, 2015, 5(1): 9-17 (doi: 10.5923/j.ijmb.20150501.02).

10. Kwon H.J., Jung N.S., Han S.B., Park S.B. Evaluation of antioxidant activity of Amaranthus hypochondriacus L. extract using cyclic voltammetry. Electrochemistry, 2019, 87(6): 336-340 (doi: 10.5796/electrochemistry.18-00097).

11. Karamać M., Gai F., Longato E., Meineri G., Janiak M., Amarowicz R., Peiretti P.G. Antioxidant activity and phenolic composition of amaranth (Amaranthus caudatus) during plant growth. Antioxidants, 2019, 8(6): 173 (doi: 10.3390/antiox8060173).

12. Гинс М.С., Пивоваров В.Ф., Гинс В.К., Байков А.А., Платонова С.Ю., Гинс Е.М. Содержание и пигментный состав автотрофной и гетеротрофной ткани листьев амаранта вида A. tricolor L. Овощи России, 2016, 3(32): 79-83 (doi: 10.18619/2072-9146-2016-3-79-83).

13. Iwamoto K., Fukuda H., Sugiyama M. Elimination of POR expression correlates with red leaf formation in Amaranthus tricolor. The Plant Journal, 2001, 27(4): 275-284 (doi: 10.1046/j.1365313x.2001.01082.x).

14. Wang Q.M., Cui J., Dai H., Zhou Y., Li N., Zhang Z. Comparative transcriptome profiling of genes and pathways involved in leaf-patterning of Clivia miniata var. variegata. Gene, 2018, 677: 280-288 (doi: 10.1016/j.gene.2018.07.075).

15. Liu S., Zheng X., Pan J., Peng L., Cheng C., Wang X., Zhao C., Zhang Z., Lin Y., XuHan X., Lai Z.-X. RNA-sequencing analysis reveals betalains metabolism in the leaf of Amaranthus tricolor L. PLoS ONE, 2019, 14(4): e0216001 (doi: 10.1371/journal.pone.0216001).

16. Khandaker L., Akond M., Oba S. Air temperature and sunlight intensity of different growing period affects the biomass, leaf color and betacyanin pigment accumulations in red amaranth (Amaranthus tricolor L.). Journal of Central European Agriculture, 2009, 10 (4): 439-448.

17. Мокроносов А.Т. Онтогенетический аспект фотосинтеза. М., 1981.

18. Robbins R.J. Phenolic acids in foods: an overview of analytical methodology. Journal of Agricultural and Food Chemistry, 2003, 51(10): 2866-2887 (doi: 10.1021/jf026182t).

19. Смашевский Н.Д., Ионова Л.П. Антивитамины в пище, биологическое действие, распространение и применение. Астраханский вестник экологического образования, 2016, 2(36): $54-66$.

20. Upchurch R.G. Fatty acid unsaturation, mobilization, and regulation in the response of plants to stress. Biotechnology Letters, 2008, 30(6): 967-977 (doi: 10.1007/s10529-008-9639-z).

21. Yadav S.K. Cold stress tolerance mechanisms in plants. A review. Agronomy for Sustainable Development, 2010, 30(3): 515-527 (doi: 10.1051/agro/2009050).

22. Ибрагимова С.С., Горелова В.В., Кочетов А.В., Шумный В.К. Роль различных метаболитов в формировании стрессоустойчивости растений. Вестник Новосибирского государственного университета. Серия: Биология, клиническая медицина, 2010, 8(3): 98-103.

23. Яхин О.И., Лубянов А.А., Калимуллина З.Ф., Батраев Р.А. Влияние регуляторов роста на стресс-индуцируемое накопление свободных аминокислот в растениях пшеницы. Известия Оренбургского государственного аграрного университета, 2012, 1(33): 38-40.

24. Луценко М.Т. Включение экзогенно поступающего в организм сквалена в синтез холестерина в печени. Сибирский научный медицинский журнал, 2010, 30(6): 152-154.

25. Гинс М.С., Гинс В.К., Мотылева С.М., Куликов И.М., Медведев С.М., Пивоваров В.Ф., Мертвищева М.Е. Идентификация метаболитов с антиоксидантными свойствами в листьях овощного амаранта (Amaranthus tricolor L.) Сельскохозяйственная биология, 2017, 52(5): 1030-1040 (doi: 10.15389/agrobiology.2017.5.1030rus).

26. Высочина Г.И. Амарант (Amaranthus L.): химический состав и перспективы использования (обзор). Химия растительного сырья, 2013, 2: 5-14 (doi: 10.14258/jcprm.1302005).

27. Запрометов М.Н. Фенольные соединения: Распространение, метаболизм и функции в растениях. М., 1993.

28. Hofer B. Recent developments in the enzymatic O-glycosylation of flavonoids. Applied Microbiology and Biotechnology, 2016, 100(10): 4269-4281 (doi: 10.1007/s00253-016-7465-0).

29. Булдагов А.С. Пищевые добавки. СПб, 1996.

30. Шкарина Е.И., Максимова Т.В., Никулина И.Н., Лозовская Е.П., Чумакова З.В., Пахомов В.П., Сапежинский И.М., Арзамасцев А.П. О влиянии биологически активных веществ на антиоксидантную активность фитопрепаратов. Химико-фармацевтический журнал, 2001, 35(6): 40-47.

31. Кретович В.Л. Биохимия растений. М., 1980.

32. Корулькин Д.Ю., Абилов Ж.А., Музычкина Р.А., Толстиков Г.А. Природные флавоноиды. 
Новосибирск, 2007.

33. Agarwal A.G., Khan M.I., Singh K., Sidhu O.P. Isolation, identification and quantification of bioactive compounds from Amaranthus hypochondriacus leaf extract: a vital source of potent natural antioxidants. International Journal of Research in Pharmaceutical Sciences, 2019, 10(12): 5632-5638 (doi: 10.13040/IJPSR.0975-8232.10(12).5632-38).

34. Nimbalkar M.S., Pai S.R., Pawar N.V., Oulkar D., Dixit G.B. Free amino acid profiling in grain amaranth using LC-MS/MS. Food Chemistry, 2012, 134(4): 2565-2569 (doi: 10.1016/j.foodchem.2012.04.057).

35. Guo S.-H., Hu N., Li Q.-S., Yang P., Wang L.-L., Xu Z.-M., Chen H.-J., He B.-Y., Zeng E.-Y. Response of edible amaranth cultivar to salt stress led to $\mathrm{Cd}$ mobilization in rhizosphere soil: a metabolomic analysis. Environmental Pollution, 2018, 241: 422-431 (doi: 10.1016/j.envpol.2018.05.018).

36. Pivovarov V.F., Gins M.S., Gins V.K. Innovative beverage production technologies based on Amaranth biomass. IOP Conference Series: Earth and Environmental Science, 2019, 395: 012090 (doi: 10.1088/1755-1315/395/1/012090).

37. Бубнова М.Г., Аронов Д.М., Перова Н.В., Чудакова И.В., Мелькина О.Е., Лобикова С.В., Жасминова В.Г. Никотиновая кислота (пролонгированная форма эндурацин) повышает толерантность липид-транспортной системы к атерогенному воздействию пищевых жиров. Клиническая фармакология и терапия, 2002, 11(4): 26-30.

38. Бышевский А.Ш., Галян С.Л., Дементьева И.А., Рудзевич А.В. Ретинол, токоферол и аскорбат, гемостаз и перекисное окисление липидов. Тромбоз, гемостаз и реология, 2009, 4(40): 16-32.

39. Clemente A.C., Desai P.V. Evaluation of the hematological, hypoglyces, hypolipidemic and antioxidant properties of Amaranthus tricolor leaf extract in rat. Tropical Journal of Pharmaceutical Research, 2011, 10(5): 595-602 (doi: 10.4314/tjpr.v10i5.8).

40. Al-Dosari M.S. The effectiveness of ethanolic extract of Amaranthus tricolor L.: a natural hepatoprotective agent. The American Journal of Chinese Medicine, 2010, 38(6): 1051-1064 (doi: $10.1142 / \mathrm{S} 0192415 \mathrm{X} 10008469)$.

41. Aneja S., Vats M., Aggarwal S., Sardana S. Phytochemistry and hepatoprotective activity of aqueous extract of Amaranthus tricolor Linn. roots. Journal of Ayurveda and Integrative Medicine, 2013, 4(4): 211-215 (doi: 10.4103/0975-9476.123693).

42. Biswas M., Dey S., Sen R. Betalains from Amaranthus tricolor L. Journal of Pharmacognosy and Phytochemistry, 2013, 1(8): 7-95.

43. Rahmatullah M., Hosain M., Rahman S., Rahman S., Akter M., Rahman F., Rehana F., Munmun M., Kalpana M.A. Antyhyperglycaemic and antinociceptive activity evaluation of methanolic extract of whole plant of Amaranthus tricolor L. (Amaranthaceae). African Journal of Traditional, Complementary and Alternative Medicines, 2013, 10(5): 408-411 (doi: 10.4314/ajtcam.v10i5.31).

44. Nimbalkar M., Pawar N., Pai S., Dixit G. Synchronized variations in levels of essential amino acids during germination in grain Amaranth. Brazilian Journal of Botany, 2020, 43: 481-491 (doi: 10.1007/s40415-020-00624-5).

45. Chmelík Z., Šnejdrlová M., Vrablík M. Amaranth as a potential dietary adjunct of lifestyle modification to improve cardiovascular risk profile. Nutrition Research, 2019, 72: 36-45 (doi: 10.1016/j.nutres.2019.09.006).

46. Rocchetti G., Tomas M., Zhang L., Zengin G., Lucini L., Capanoglu E. Red beet (Beta vulgaris) and amaranth (Amaranthus sp.) microgreens: Effect of storage and in vitro gastrointestinal digestion on the untargeted metabolomic profile. Food Chemistry, 2020, 332: 127415 (doi: 10.1016/j.foodchem.2020.127415).

1ФГБНУ Федеральный научный центр овощеводства, 143080 Россия, Московская обл., Одинцовский р-н, пос. ВНИИССОК, ул. Селекционная, 14,

e-mail: anirr@bk.ru 凹, anirr67@yandex.ru, pivovarov@vniissok.ru;

2ФГБНУ Всероссийский селекционно-технологический

институт садоводства и питомниководства,

115598 Россия, г. Москва, ул. Загорьевская, 4,

e-mail: motyleva_svetlana@mail.ru, vstisp@vstisp.org, mos_vstisp@mail.ru;

ЗФГАОУ ВО Российский университет дружббы народов,

117198 Россия, г. Москва, ул. Миклухо-Маклая, 6

Sel'skokhozyaistvennaya biologiya [Agricultural Biology], 2020, V. 55, № 5, pp. 920-931

\title{
THE METABOLITES OF AUTOTROPHIC AND HETEROTROPHIC LEAVES OF Amaranthus tricolor L. EARLY SPLENDOR VARIETY
}

\author{
M.S. Gins ${ }^{1,3}$, V.K. Gins ${ }^{1}$, S.M. Motyleva' ${ }^{2}$ I.M. Kulikov², S.M. Medvedev², \\ V.F. Pivovarov ${ }^{1}$
}


${ }^{1}$ Federal Research Center for Vegetable Growing, 14, ul. Selektsionnaya, pos. VNIISSOK, Odintsovskii Region, Moscow Province, 143080 Russia, e-mail anirr@bk.ru (corresponding author $\varangle$ ), anirr67@yandex.ru, pivovarov@vniissok.ru;

${ }^{2}$ All-Russian Horticultural Institute for Breeding, Agrotechnology and Nursery, 4, ul. Zagor'evskaya, Moscow, 115598 Russia e-mail motyleva_svetlana@mail.ru,vstisp@vstisp.org, mos_vstisp@mail.ru;

${ }^{3}$ People's Friendship University of Russia (RUDN University), 6, ul. Miklukho-Maklaya, Moscow, 117198 Russia ORCID:

Gins M.S. orcid.org/0000-0001-5995-2696

Gins V.K. orcid.org/0000-0002-7053-4345

Motyleva S.M. orcid.org/0000-0003-3399-1958

The authors declare no conflict of interests

Received August 5, 2020

Kulikov I.M. orcid.org/0000-0001-8071-0931

Medvedev S.M. orcid.org/0000-0002-4747-9835

Pivovarov V.F. orcid.org/0000-0003-1350-5852

doi: 10.15389/agrobiology.2020.5.920eng

\section{Abstract}

An important area of systemic biology (metabolomics) is the study of the composition and properties of low-molecular metabolites of agricultural plants with different modes of nutrition. The use of metabolic technologies expands the possibilities of analyzing biochemical changes in the composition and structural modifications of metabolites occurring during the transition from autotrophic to heterotrophic nutrition. Most photosynthetic plants are capable of autotrophic nutrition, but in their lifetime, there are periods of appearance of the achlorophyllic organs which receive nutritients from the organic substances stored earlier. Thus, among Amaranthus tricolor L. plants there are varieties with leaves which differ from each other in the way of nutrition. For example, Early Splendor variety plants form brightly colored red heterotrophic leaves along with green photosynthesis leaf blades at the end of the vegetative phase. The comparative study of the low-molecular metabolites composition in these leaves is important for understanding the relationship between heterotrophic and autotrophic nutrition in the whole plant. In this paper, significant qualitative differences in metabolites composition between autotrophic and heterotrophic leaves were stated for the first time during the metabolome analysis of water and alcohol extracts of heterotrophic and autotrophic amaranth leaves of Early Splendor variety using the method of gas chromato-mass spectrometry. It was found that the low-molecular metabolites of autotrophic and heterotrophic leaves contained both non-specific metabolites common for both type of nutrition and specific metabolites characteristic for each of the ways separately. On the one hand, it indicates the close interaction between two ways of nutrition and, on the other hand, the ability to synthesize and modify the metabolites which demonstrates partial autonomy of heterotrophic leaves. The purpose of the work is to study the composition of low-molecular metabolites and to identify new biologically active metabolites antioxidants in heterotrophic and autotrophic amaranth leaves of Early Splendor variety. Experiments were carried out in 2017-2019 with amaranth plants of the Early Splendor variety at the end of floweringthe beginning of seed formation phase. The plants were grown in a film greenhouse (the Federal Research Center for Vegetable Growing). The fresh red-colored heterotrophic leaves formed at the top of the main stem and the underlying photosynthetic leaves with a fully formed leaf blade were collected for analysis. The leaves were homogenized (T18 homogenizer, IKA, Germany) and extracted for $30 \mathrm{~min}$ at $24{ }^{\circ} \mathrm{C}$ with either $96 \%$ ethanol or distilled water (leaves weighing batch: extragent 1:10). The metabolites were profiled by gas chromato-mass spectrometry method (GH-MC) with a chromograph GH-MC JMS-Q1050GC (JEOL Ltd., Japan). According to the mass spectra library of the NIST-5 National Institute of Standards and Technology (USA), a total of 87 metabolites were totally identified. Heterotrophic leaves contained 19 substances in water extracts and 38 metabolites in alcohol extracts, while photosynthetic leaves contained 21 substances in the water extract and 57 metabolites in alcohol extracts. Twenty-nine identical metabolites were found in water and alcohol extracts. In heterotrophic and autotrophic amaranth leaves of Early Splendor variety squalene $(\mathrm{C} 30 \mathrm{H} 50)$, a biologically active compound with antioxidant properties was identified for the first time. Also, in heterotrophic leaves monopelargonine (monononanoin) $\left(\mathrm{C}_{15} \mathrm{H}_{11} \mathrm{O} 7\right)$ was identified. Monopelargonine is an intermediate product of flavonoid o-glycosylation, is referred to phenolic compounds and possesses high antioxidant activity. Metabolites have been identified that are present in both autotrophic and heterotrophic amaranth leaves, which suggests a close interaction of the two types of nutrition during the appearance, growth and development of heterotrophic leaves. At the same time, photosynthesizing leaves serve as donors of key metabolites for heterotrophic leaves, while the latter are not only acceptors, but also can synthesize and modify metabolites necessary for cell formation. Due to revealed rich composition of carbohydrates, essential amino acids, lipids and organic acids, the photosynthesizing leaf biomass is a source of antioxidants and biologically active substances. It should be stressed that not all metabolites were identified. Nevertheless, the set of metabolites that we identified in the photosynthetic leaves allows us to suggest these substances to be key and sufficient compounds for the construction and functioning of cells and tissues in heterotrophic leaves.

Keywords: Amaranthus tricolor, low-molecular antioxidants, autotrophic leaf, heterotrophic leaf, gas chromatography, mass spectrometry. 